\title{
INTEGRASI METODE IPMS DAN SMART SYSTEM DALAM PENGUKURAN KINERJA PERGURUAN TINGGI
}

\author{
PETIR PAPILO \\ Program Studi Teknik Industri - Fakultas Sains dan Teknologi, UIN Sultan Syarif Kasim Riau \\ Laman: pilo_ukm@yahoo.com
}

\begin{abstract}
ABSTRAK
Kajian ini bertujuan untuk mengetahui tingkat pencapaian kinerja pada organisasi pendidikan khususnya dalam lingkup suatu fakultas.Dengan menggunakan metode IPMS telah ditetapkan sebanyak 32 strategi objektif yang ingin dicapai yang terangkum kedalam 9 (Sembilan) aspek yang merupakan perspektif-perspektif yang ada pada Model SMART System. Dari analisis prioritas yang telah dilakukan, terdapat lima faktor utama yang menjadi fokus perhatian dan menjadi indikator penentu keberhasilan pencapaian visi dan misi yang telah ditetapkan oleh Fakultas " $X$ ”. Dari pengukuran yang telah dilakukan diperoleh nilai indeks kinerja Fakultas " $X$ ” berada pada tingkat 3,72 pada tahun 2011. Mengacu kepada standar taraf pencapaian yang ada, dapat disimpulkan bahwa pencapaian kinerja Fakultas " $X$ " masih jauh dari target yang diharapkan, yakni pada taraf antara 8 hingga 9.
\end{abstract}

Kata kunci: Kinerja, Metode IPMS, Model SMART System

\begin{abstract}
This study aimed to determine the level of achievement of the organization, performance in education, especially within the scope of a faculty. By using this IPMS method, it has been established over 32 objective strategy to be achieved that were summarized into 9 (nine) aspects are perspectives that exist on the SMART System Model. From the analysis of the priorities that had been made, there are five main factors that became the focus of attention and a critical indicator of success in achieving the vision and mission set by the " $X$ " Faculty.From the measurements that had been performed Faculty performance index values were 3.72 level. Referod to a standard level of achievement, it could be concluded that the achievement of the Faculty " $X$ ", was still far from the expected target, at the 8 to 9 level.
\end{abstract}

Key words: IPMS Method, Performance, SMART System Model

\section{PENDAHULUAN}

Direktorat Jenderal Pendidikan Tinggi melalui Badan Akreditasi Nasional Perguruan Tinggi (BAN PT) mensyaratkan bahwa setiap Perguruan Tinggi wajib menjalani proses akreditasi sebagai wujud penilaian kinerja pelaksanaan organisasi secara menyeluruh. Namun, yang menjadi permasalahan adalah pengukuran kinerja menurut standar akreditasi yang diterapkan oleh BAN PT lebih cenderung bersifat administratif, dimana penilaian lebih banyak ditekankan kepada kelengkapan data yang terdokumentasi di dalam laporan administrasi harian yang ada pada sebuah Perguruan Tinggi. Padahal semestinya penilaian kinerja perlu dikorelasikan dengan rencana strategis jangka panjang meliputi visi, misi dan rencana strategis sebuah Perguruan Tinggi (Suartika dkk., 2007).

Fakultas "X", selalu berupaya melakukan perbaikan terhadap sistim pendidikan yang dilaksanakan. Penilaian kinerja terhadap setiap unit program yang ada, selalu dilakukan terutama terhadap kinerja pendidikan yang diberikan oleh para dosen, dengan melibatkan berbagai pihak seperti para pelaksana manajemen, mulai dari Dekan hingga para Ketua Program Studi, para dosen serta para mahasiswa. Namun yang menjadi permasalahan adalah penilaian kinerja yang bersifat komprehensif terhadap setiap proses-proses akademik belum pernah dilakukan.Oleh karenanya, penelitian ini dirasa sangat penting untuk dilaksanakan. Melalui penelitian ini diharapkan akan dapat memberikan gambaran pencapaian kinerja Fakultas " $\mathrm{X}$ " atas proses-proses yang telah dilaksanakan. Sehingga dari hasil penelitian yang diperoleh, diharapkan pula akan menjadi landasan bagi Fakultas "X" dalam melakukan perbaikan-perbaikan di masa mendatang.

Pada saat ini, metode pengukuran kinerja sudah berkembang sangat pesat. Para akademisi dan praktisi telah banyak mengimplementasikan 
metode-metode baru dalam pengukuran kinerja organisasi, antara lain metode Balanced Scorecard, Integrated Performance Measurement System (IPMS) dan Strategic Management Analysis and Reporting Techniques (SMART) System (Pratiwi, 2009). Sebelum dikembangkannya metode-metode pengukuran kinerja tersebut, banyak organisasi melakukan pengukuran kinerja berdasarkan kepada aspek keuangan saja, dalam hal ini dengan mengukur rasio ketercapaian target keuangan yang diperbandingkan setiap tahunnya. Namun jika hanya mengandalkan rasio keuangan saja, metode tersebut akan kurang tepat jika diterapkan pada organisasi yang bersifat non profit. Oleh karenanya pengembangan metode pengukuran kinerja dengan berdasarkan kepada aspek non finansial akan sangat membantu organisasi yang berorientasi non profit untuk menilai pencapaian kinerja, yang salah satunya adalah Perguruan Tinggi.

IPMS dan SMART System merupakan metoda pengukuran kinerja terkini yang mulai digunakan oleh organisasi yang ingin mengetahui tingkat pencapaian kinerjanya. Metode (IPMS) adalah model sistim pengukuran kinerja yang dikembangkan di Center for Strategic Manufacturing dari University of Strathclyde, Glasgow. Tujuan dari model IPMS agar sistim pengukuran kinerja lebih terintegrasi, efektif, dan efisien.

SMART System merupakan model yang dibuat oleh Wang Laboratory dengan menggunakan strategi objektif sebagai titik awal perancangannya. Perspektif berdasarkan strategi objektifnya diyakini mampu menunjang operasional organisasi (Pratiwi, 2009). Susunan strategiobjektif disusun sesuai tingkatan dalam manajemen organisasi sehingga tersusun seperti piramida. Banyak organisasi kecil dan menengah tidak memiliki visi dan strategi yang jelas. Orientasi yang lebih terfokus pada kinerja operasional lebih mendominasi. Oleh karena itu, model ini sering dipakai oleh organisasi kecil dan menengah untuk mengukur kinerja organisasinya. Melalui Gambar 1 dapat diperlihatkan perspektif yang terdapat pada model SMART System menurut tingkatan manajemen dalam suatu organisasi.

\section{METODE}

Secara umum pengukuran kinerja suatu organisasi dengan menggunakan Metode IPMS dan SMART System dapat dilaksanakan dengan terlebih dahulu menentukan strategi objektif organisasi. Dengan menggunakan kerangka kerja SMART system (seperti terlihat pada Gambar 1). Sedangkan untuk menentukan strategi objektif untuk setiap level manajemen Fakultas "X", dilakukan dengan menggunakan metode IPMS. Melalui jejak pendapat dengan para pengambil keputusan di tingkat Fakultas "X" serta pimpinan ditingkat Program Studi yang ada telah diperoleh beberapa strategi objektif yang ingin dicapai.

Mengacu kepada SMART System, untuk level Unit Bisnis terdapat 2 (dua) perspektif yakni financial dan market. Perspektif financial ini

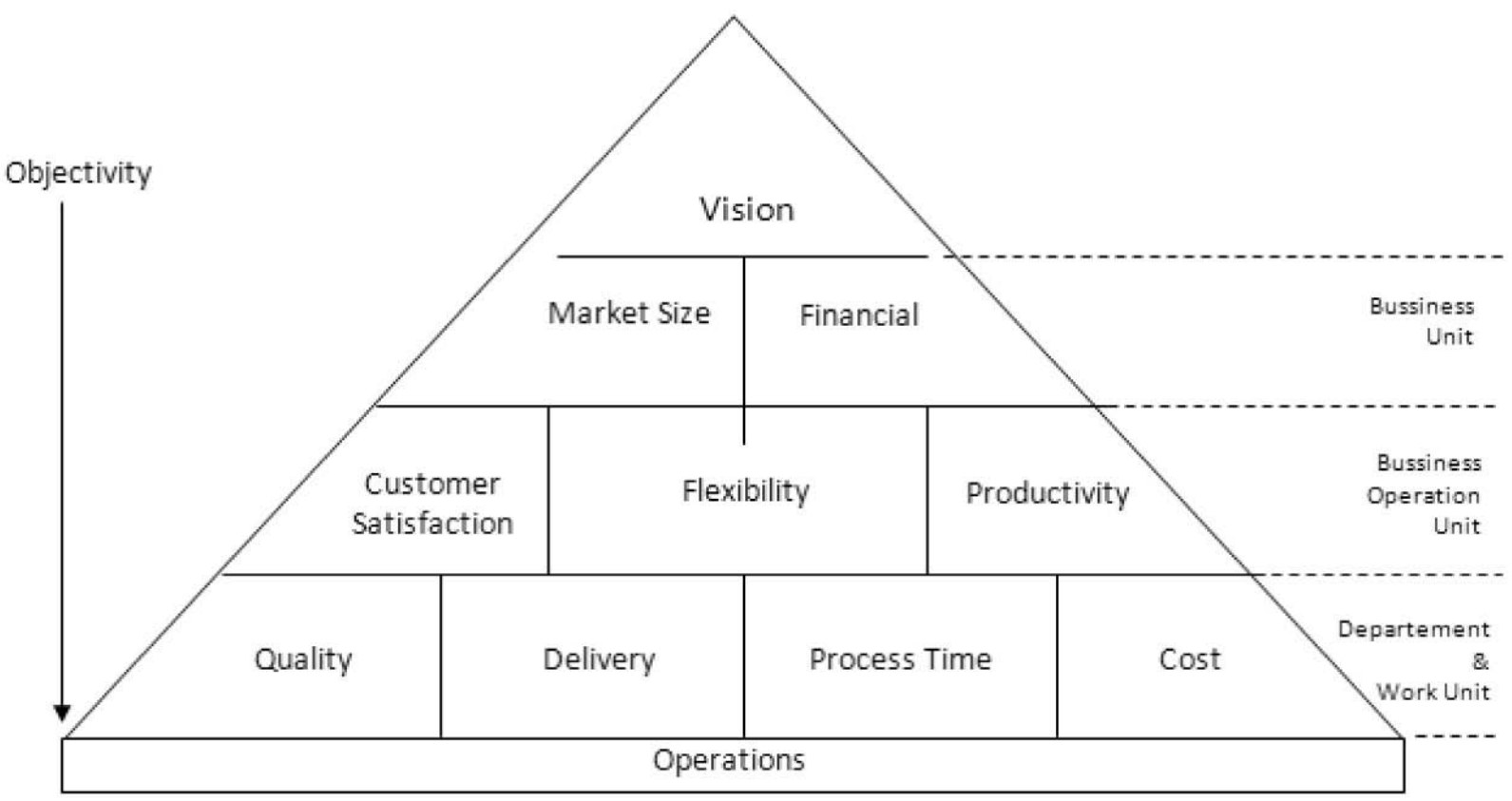

Sumber: Vanany dan Sugianto, 2007

Gambar 1. Persepektif pada SMART System 
berkait erat dengan aspek keuangan Fakultas " $\mathrm{X}$ " yang diperoleh berdasarkan berbagai sumber pemasukan. Dengan menggunakan metode IPMS telah diperoleh 5 (lima) strategi objektif yang ingin dicapai guna meningkatkan sumber pemasukan keuangan fakultas, antara lain iuran pendidikan mahasiswa, hibah luar negeri, hibah pemerintah, hibah unit bisnis, serta hasil kerja sama dan kemitraan. Sedangkan perspektif market, merupakan perspektif yang menjelaskan tentang ukuran dan ruang lingkup penyaluran lulusan setiap Program Studi yang ada di Fakultas "X" di dalam berbagai peluang dunia kerja. Pada aspek ini strategi objektif diarahkan pada kesesuaian antara bidang pekerjaan dengan kompetensi yang ada di setiap Program Studi Fakultas "X".

Pada level Unit Operasi Bisnis, terdapat 3 perspektif, yakni peningkatan produktitvitas, fleksibilitas serta fokus kepada pelanggan (customer). Perspektif produktivitas (productivity) berkaitan erat dengan tingkat kemampuan Fakultas dalam memaksimalkan perolehan hasil dengan tetap berupaya melakukan efisiensi pada aspek-aspek seperti peningkatan jumlah mahasiswa, percepatan masa studi mahasiswa, peningkatan jumlah dosen serta peningkatan hasil-hasil karya ilmiah para dosen dan mahasiswa. Sedangkan perspektif flexibility berkaitan erat dengan pemanfaatan sumber daya secara bersama antar unit yang ada di Fakultas "X". Pada perspektif ini terdapat 4 (empat) strategi objektif yang ingin dicapai antara lain adalah penambahan jumlah kelas baru, pemeliharaan fasilitas bersama, penggunaan kelas secara bersama serta penggunaan tenaga dosen mata kuliah yang sama antar program studi yang ada di Fakultas "X". Perspektif customer merupakan perspektif yang menjelaskan upaya pelayanan yang diberikan oleh Fakultas " $\mathrm{X}$ " terhadap para pelanggan, baik pelanggan fakultas internal (dalam hal ini para mahasiswa, dosen dan staf) maupun pelanggan eksternal (pengguna lulusan). Pada perspektif ini ditetapkan 4 (empat) strategi objektif yang ingin dicapai, antara lain perbaikan waktu pelayanan administratif, penurunan tingkat keluhan mahasiswa, peningkatan kepuasan dosen atas beban akademik yang akan dipikul serta insentif yang akan diterima.

Pada level Departemen dan Unit Kerja, terdapat 4 (empat) perspektif antara lain berkaitan dengan pembiayaan (cost), waktu proses (process time), waktu penyampaian (delivery) serta aspek mutu (quality). Perspektif cost berkaitan erat dengan pengelolaan dan pembiayaan pendidikan. Pada perspektif ini ditetapkan sebanyak 4 (empat) strategi objektif yang ingin dicapai, antara lain tingkat kenaikan iuran pendidikan mahasiswa setiap tahun ajaran, pembiayaan pendidikan dan pengajaran, pembiayaan kegiatan praktikum serta pembiayaan kegiatan kemahasiswaan. Perspektif process time, merupakan perspektif yang menjelaskan tentang durasi waktu yang diperlukan oleh setiap dosen ataupun mahasiswa didalam melaksanakan fungsi-fungsi pembelajaran. Pada perspektif ini ditetapkan sebanyak 2 (dua) strategi objektif yang ingin dilaksanakan, antara lain durasi waktu setiap pertemuan perkuliahan, ketercapaian target jumlah pertemuan selama satu semester perkuliahan. Perspektif delivery, merupakan perspektif yang menjelaskan tentang masa yang dibutuhkan bagi mahasiswa di dalam menyelesaikan pendidikan. Pada perspektif ini ditetapkan sebanyak 2 (dua) strategi objektif, yakni lamanya masa studi mahasiswa per angkatan serta masa menunggu lulusan dalam memperoleh pekerjaan. Sedangkan perspektif quality, berkaitan erat dengan kinerja proses dan hasil yang diberikan oleh Fakultas bagi para lulusannya. Terdapat 3 (tiga) strategi objektif yang ingin dicapai, antara lain peningkatan prestasi akademik para lulusan, peningkatan mutu akademik para dosen serta indeks kinerja dosen secara menyeluruh.

Setelah organisasi dalam hal ini Fakultas "X" menetapkan strategi objektif yang ingin dicapai, dilakukan pembobotan KPI dengan Analitycal Hierarchy Process (AHP) (Saaty, 1993) didasarkan pada strukturisasi hirarki sistim pengukuran kinerja SMART System. Pada dasarnya proses hirarki analitik merupakan penyederhanaan suatu masalah yang kompleks yang tidak terstruktur, strategik, dan dinamik kedalam bagian komponennya, serta menata bagian atau variabel dalam suatu susunan hierarkhi, (Pratiwi, 2009). Prinsip kerja proses hierarkhi analitik dimulai dengan mengidentifikasi sistim, lalu diikuti dengan penyusunan hierarkhi, dan penyusunan matriks pendapat.

Pembobotan diperlukan agar preferensi dari pihak Fakultas terhadap tingkat kepentingan kriteria (Perspektif, Strategi, dan KPI) dapat diketahui. Nilai bobot masing-masing KPI diperoleh dengan menggunakan perangkat lunak Expert Choice. Untuk keperluan pengumpulan data, terlebih dahulu dirancang instrumen penelitian berupa kuesioner. Desain kuesioner bersifat tertutup dan diberikan kepada pimpinan tingkat Fakultas dan Jurusan. Hasil data dari kuesioner kemudian diolah dan dianalisis. Bobot yang didapatkan harus konsisten dengan syarat inconcistency ratio harus kurang dari atau sama dengan 0,1. Bila tidak konsisten, maka dilakukan konfirmasi kembali kepada pihak Fakultas dan jurusan hingga tercapai tingkat konsistensi yang disyaratkan. 
Setelah ditetapkan bobot kinerja setiap yang diharapkan dari masing-masing KPI, maka dilakukan proses pengukuran kinerja yang bertujuan untuk mengetahui apakah selama pelaksanaan kinerja terdapat deviasi dari rencana yang telah ditentukan. Data yang diperlukan dalam pengukuran berupa datasekunder dari pihak Fakultas. Data yang di peroleh tersebut dikonversikan dalam bentuk angka atau skor. Adapun sistim penyekoran yang digunakan dalam penelitian ini adalah dengan menggunakan metode OMAX (Objective Matrix) untuk setiap KPI. Skor OMAX terletak pada rentang 1 s.d. 10 dimana nilai 1 menunjukkan bahwa kinerja KPI sangat jauh dibawah target atau dapat dikatakan kinerja terjelek, nilai 7 menunjukkan kinerja KPI sama dengan yang telah ditargetkan, dan nilai 10 menunjukkan KPI telah mencapai target dan jauh melampaui target. Nilai 2,3,4,5, dan 6 merupakan nilai interpolasi dalam rentang 1 s.d. 7, dan nilai 8 dan 9 adalah nilai interpolasi antara nilai 7 dan 10.

\section{HASIL DAN PEMBAHASAN}

Dalam penelitian ini, perspektif-perspektif yang terdapat pada Model SMART System digunakan sebagai dasar untuk menentukan strategi objektif yang diharap oleh Fakultas.Untuk menentukan strategi objektif yang sesuai dengan kebutuhan Fakultas berdasarkan perspektif yang ada, maka digunakan metode IPMS.Setelah menetapkan berbagai strategi objektif, maka ditentukan ukuran-ukuran keberhasilan yang menjadi sasaran pengembangan di setiap bidang yang ada di Fakultas "X". Ukuran-ukuran keberhasilan tersebut tidak lain merupakan indikator-indikator kunci di dalam mengukur tingkat kemampuan dan pencapaian yang telah diraih Fakultas "X". Adapun strategi objektif serta KPI yang menjadi ukuran kinerja Fakultas dapat dilihat pada Tabel 1.

Penentuan prioritas arah kebijakan pengembangan Fakultas "X", dapat diukur dengan menyusun suatu matrik perbandingan dan perhitungan bobot setiap perspektif yang diperbandingkan. Dari tanggapan yang diberikan oleh pengambil kebijakan yang ada di tingkat Fakultas, maka dapat direkap hasil skoring dan bobot berbagai perspektif yang ada seperti terlihat pada Tabel 2 .

Tabel 2. Nilai Bobot Tiap Perspektif

\begin{tabular}{lccc}
\hline \multicolumn{1}{c}{ Perspektif } & Skor & Bobot & Rangking Prioritas \\
\hline Financial & 1,5119 & 0,1680 & 2 \\
Market Size & 1,0207 & 0,1134 & 4 \\
Productivity & 0,9855 & 0,1095 & 5 \\
Flexibility & 0,3640 & 0,0404 & 9 \\
Customer Satisfaction & 1,2669 & 0,1408 & 3 \\
Cost & 0,5054 & 0,0562 & 8 \\
Process Time & 0,6809 & 0,0757 & 7 \\
Delivery & 0,8015 & 0,0891 & 6 \\
Quality & 1,8633 & 0,2070 & 1 \\
\hline
\end{tabular}

Pengukuran kinerja dengan menggunakan metode SMART System yang terintegrasi dengan metode IPMS ini, mengarahkan hasil penilaian kepada perspektif-perspektif yang dianggap penting dalam upaya pencapaian target organisasi Fakultas "X". Dengan pendekatan model SMART System ditetapkan sebanyak 9 (sembilan) perspektif yang menjadi fokus perhatian dalam upaya peningkatan kinerja dan pencapaian target organisasi. Namun dalam kajian ini, pihak pengambil keputusan melalui penilaian yang diberikan dan analisis prioritas pada Tabel 2, hanya 5 perspektif yang dianggap paling

Tabel 1. Strategi Objektif dan Key Performance Indicator (KPI) Fakultas "X"

\begin{tabular}{|c|c|c|c|}
\hline Level & Perspektif & Strategi Objektif & Key Performance Indikator \\
\hline \multirow[t]{9}{*}{ Unit Bisnis } & Financial & $\begin{array}{l}\text { Peningkatan pendapatan yang bersumber dari } \\
\text { mahasiswa }\end{array}$ & $\begin{array}{l}\text { \% Peningkatan pendapatan total dari SPP } \\
\text { mahasiswa (KPI-1) }\end{array}$ \\
\hline & & Peningkatan pendapatan dari hibah luar negeri & $\begin{array}{l}\text { \% Peningkatan pendapatan hibah luar negeri } \\
\text { (KPI-2) }\end{array}$ \\
\hline & & Peningkatan pendapatan dari hibah Pemerintah & $\begin{array}{l}\text { \% Peningkatan pendapatan dari bantuan } \\
\text { pemerintah (KPI-3) }\end{array}$ \\
\hline & & Peningkatan pendapatan dari unit bisnis Universitas & $\begin{array}{l}\% \text { Peningkatan pendapatan dari unit bisnis (BLU) } \\
\text { Fakultas (KPI-4) }\end{array}$ \\
\hline & & $\begin{array}{l}\text { Peningkatan pendapatan dari hasil proyek } \\
\text { kerjasama dan kemitraan }\end{array}$ & $\begin{array}{l}\text { \% Peningkatan pendapatan dari hasil proyek } \\
\text { kerjasama dan kemitraan (KPI-5) }\end{array}$ \\
\hline & Market Size & $\begin{array}{l}\text { Ketersediaan bidang pekerjaan yang sesuai dengan } \\
\text { kompetensi di Fakultas "X" }\end{array}$ & $\begin{array}{l}\text { Tingkat ketersediaan bidang pekerjaan yang } \\
\text { sesuai dengan kompetensi di Fakultas "X" (KPI-6) }\end{array}$ \\
\hline & & $\begin{array}{l}\text { Ketersediaan bidang pekerjaan diluar kompetensi di } \\
\text { Fakultas "X" }\end{array}$ & $\begin{array}{l}\text { Tingkat ketersediaan bidang pekerjaan diluar } \\
\text { kompetensi di Fakultas "X" (KPI-7) }\end{array}$ \\
\hline & & $\begin{array}{l}\text { Peningkatan daya saing mahasiswa pada bidang } \\
\text { pekerjaan sesuai kompetensi }\end{array}$ & $\begin{array}{l}\text { Tingkat serapan lulusan pada pekerjaan sesuai } \\
\text { dengan kompetensi (KPI-8) }\end{array}$ \\
\hline & & $\begin{array}{l}\text { Peningkatan daya saing mahasiswa pada bidang } \\
\text { pekerjaan diluar kompetensi }\end{array}$ & $\begin{array}{l}\text { Tingkat serapan lulusan pada pekerjaan diluar } \\
\text { dengan kompetensi (KPI-9) }\end{array}$ \\
\hline
\end{tabular}


Lanjutan Tabel 1.

\begin{tabular}{|c|c|c|c|}
\hline Level & Perspektif & Strategi Objektif & Key Performance Indikator \\
\hline \multirow{12}{*}{$\begin{array}{l}\text { Unit } \\
\text { Operasi } \\
\text { Bisnis }\end{array}$} & \multirow[t]{4}{*}{ Productivity } & Peningkatan jumlah penerimaan mahasiswa baru & $\begin{array}{l}\text { Jumlah penerimaan rata-rata mahasiswa baru } \\
\text { per tahun ajaran (KPI-10) }\end{array}$ \\
\hline & & Peningkatan jumlah mahasiswa tamat tepat waktu & \% Jumlah mahasiswa tamat tepat waktu (KPI-11) \\
\hline & & Peningkatan jumlah dosen & $\begin{array}{l}\text { Rasio perbandingan jumlah dosen dengan } \\
\text { mahasiswa (KPI-12) }\end{array}$ \\
\hline & & Peningkatan jumlah karya ilmiah dosen & $\begin{array}{l}\text { Rasio perbandingan jumlah karya ilmiah dengan } \\
\text { dosen (KPI-13) }\end{array}$ \\
\hline & \multirow[t]{4}{*}{ Flexibility } & Penambahan jumlah kelas baru & $\begin{array}{l}\text { Penambahan jumlah kelas baru per tahun ajaran } \\
\text { (KPI-14) }\end{array}$ \\
\hline & & Pemeliharaan fasilitas yang telah tersedia & $\begin{array}{l}\text { Persentase pemeliharaan fasilitas yang ada (KPI- } \\
\text { 15) }\end{array}$ \\
\hline & & $\begin{array}{l}\text { Penggunaan fasilitas dan kelas secara bersama } \\
\text { dengan sistim crossing }\end{array}$ & $\begin{array}{l}\text { Persentase penggunaan fasilitas dan kelas secara } \\
\text { bersama dengan sistim crossing (KPI-16) }\end{array}$ \\
\hline & & $\begin{array}{l}\text { Pemanfaatan tenaga dosen pada matakuliah dasar } \\
\text { secara bersama }\end{array}$ & $\begin{array}{l}\text { Persentase pemanfaatan jumlah dosen bersama } \\
\text { (KPI-17) }\end{array}$ \\
\hline & \multirow[t]{4}{*}{$\begin{array}{l}\text { Customer } \\
\text { Satisfaction }\end{array}$} & $\begin{array}{l}\text { Peningkatan waktu pelayanan administrasi } \\
\text { mahasiswa }\end{array}$ & $\begin{array}{l}\text { Durasi waktu pelayanan administrasi kepada } \\
\text { mahasiswa (KPI-18) }\end{array}$ \\
\hline & & Penurunan tingkat keluhan dari mahasiswa & Persentase keluhan mahasiswa (KPI-19) \\
\hline & & $\begin{array}{l}\text { Peningkatan kepuasan dosen terhadap Beban } \\
\text { Akademik Dosen (BAD) }\end{array}$ & $\begin{array}{l}\text { Tingkat kepuasan dosen terhadap jumlah honor } \\
\text { kelebihan BAD (KPI-20) }\end{array}$ \\
\hline & & $\begin{array}{l}\text { Peningkatan penyelesaian waktu pembayaran honor } \\
\text { tiap aktivitas }\end{array}$ & $\begin{array}{l}\text { Durasi waktu pembayaran honorarium tiap } \\
\text { aktivitas akademik (KPI-21) }\end{array}$ \\
\hline \multirow{13}{*}{$\begin{array}{l}\text { Departemen } \\
\text { dan Unit } \\
\text { Kerja }\end{array}$} & \multirow{4}{*}{ Cost } & $\begin{array}{l}\text { Tingkat kenaikan biaya kuliah mahasiswa per tahun } \\
\text { ajaran }\end{array}$ & $\begin{array}{l}\text { Biaya kuliah rata-rata mahasiswa tiap Prodi } \\
\text { (KPI-22) }\end{array}$ \\
\hline & & $\begin{array}{l}\text { Peningkatan pembiayaan bagi kegiatan pendidikan } \\
\text { dan pembelajaran }\end{array}$ & $\begin{array}{l}\text { Alokasi anggaran bagi pendidikan dan } \\
\text { pembelajaran (KPI-23) }\end{array}$ \\
\hline & & Peningkatan pembiayaan bagi kegiatan praktikum & $\begin{array}{l}\text { Alokasi anggaran bagi kegiatan praktikum } \\
\text { mahasiswa (KPI-24) }\end{array}$ \\
\hline & & $\begin{array}{l}\text { Peningkatan pembiayaan bagi kegiatan } \\
\text { kemahasiswaan }\end{array}$ & $\begin{array}{l}\text { Alokasi anggaran bagi kegiatan kemahasiswaan } \\
\text { (KPI-25) }\end{array}$ \\
\hline & \multirow[t]{3}{*}{$\begin{array}{l}\text { Process } \\
\text { Time }\end{array}$} & $\begin{array}{l}\text { Pemenuhan waktu proses pembelajaran sesuai } \\
\text { standar }\end{array}$ & Durasi pertemuan (waktu/sks) (KPI-26) \\
\hline & & Ketercapaian target penyelesaian materi kuliah & $\begin{array}{l}\text { Rata-rata jumlah tatap muka per semester tiap } \\
\text { dosen (KPI-27) }\end{array}$ \\
\hline & & & $\begin{array}{l}\text { Prosentase penyelesaian materi pembelajaran } \\
\text { (KPI-28) }\end{array}$ \\
\hline & \multirow[t]{3}{*}{ Delivery } & Percepatan masa kelulusan mahasiswa & Rata-rata masa studi lulusan (KPI-29) \\
\hline & & & $\begin{array}{l}\text { Rata-rata waktu penyelesaian Tugas Akhir (KPI- } \\
\text { 30) }\end{array}$ \\
\hline & & $\begin{array}{l}\text { Percepatan masa mendapatkan pekerjaan sesuai } \\
\text { atau diluar kompetensi }\end{array}$ & $\begin{array}{l}\text { Rata-rata masa tunggu memperoleh pekerjaan } \\
(\mathrm{KPI}-31)\end{array}$ \\
\hline & \multirow[t]{3}{*}{ Quality } & Peningkatan prestasi akademik para lulusan & $\begin{array}{l}\text { Indeks Prestasi kumulatif (IPK) rata-rata lulusan } \\
\text { per angkatan wisuda (KPI-32) }\end{array}$ \\
\hline & & Peningkatan mutu akademik dosen & Rata-rata jenjang pendidikan dosen (KPI-33) \\
\hline & & Peningkatan kinerja dosen secara menyeluruh & Indeks kinerja dosen (KPI-34) \\
\hline
\end{tabular}

penting dengan nilai bobot prioritas rata-rata lebih dari 0,1. Adapun kelima perspektif yang dianggap paling penting menurut penilaian para pengambil keputusan yang ada di Fakultas "X" adalah quality (bobot sama dengan 0,2070), financial (bobot sama dengan 0,1680), customer satisfaction (bobot sama dengan 0,1408), market size (bobot sama dengan 0,1134), dan productivity (bobot sama dengan $0,1095)$.

Dalam menentukan pencapaian kinerja, Fakultas "X" juga telah menetapkan nilai target KPI dari setiap perspektif. Melalui Tabel 3 berikut ini akan diperlihatkan nilai bobot setiap KPI faktor utama serta nilai target yang ingin dicapai.

Dengan menggunakan AHP, telah dapat diketahui nilai bobot dari setiap KPI. Nilai bobot ini nantinya akan digunakan untuk menghitung pencapaian kinerja setiap KPI berdasarkan nilai skor aktual yang telah diperoleh. Berdasarkan data yang ada dari masing-masing program studi yang ada di Fakultas "X", ditentukan pula nilai baseline kinerja yang akan menjadi acuan untuk menentukan nilai setiap peringkat pencapaian target kinerja setiap faktor. Sebagai contoh pada KPI 33 (Rata-rata jenjang 
Tabel 3. Nilai Bobot KPI dan Target Pencapaian

\begin{tabular}{|c|c|c|c|c|c|c|c|}
\hline No & Perspektif & $\begin{array}{c}\text { Bobot } \\
\text { Perspektif }\end{array}$ & Indikator & $\begin{array}{l}\text { No. } \\
\text { KPI }\end{array}$ & $\begin{array}{c}\text { Bobot } \\
\text { KPI }\end{array}$ & $\begin{array}{l}\text { Baseline } \\
\text { Kinerja }\end{array}$ & Target \\
\hline \multirow[t]{3}{*}{1} & Quality & 0,2070 & $\begin{array}{l}\text { Indeks Prestasi kumulatif (IPK) rata-rata } \\
\text { lulusan per angkatan wisuda }\end{array}$ & 32 & 0,416 & $1,07 \%$ & $\mathrm{~S} 3>30 \%$ \\
\hline & & & Rata-rata jenjang pendidikan dosen & 33 & 0,333 & $54,0 \%$ & $(\mathrm{IPK}>2,75)>80 \%$ \\
\hline & & & Indeks kinerja dosen & 34 & 0,251 & $21,0 \%$ & $(\mathrm{IKD}>3,0)>60 \%$ \\
\hline \multirow[t]{5}{*}{2} & Financial & 0,1680 & Hibah pemerintah & 3 & 0,4750 & $17 \%$ & Rasio $=20 \%$ \\
\hline & & & Pendapatan dari SPP mahasiswa & 1 & 0,2184 & $46 \%$ & Rasio $=30 \%$ \\
\hline & & & Hibah internasional & 2 & 0,1021 & $37 \%$ & Rasio $=20 \%$ \\
\hline & & & Pendapatan unit bisnis Fakultas & 4 & 0,1021 & 0 & Rasio $=20 \%$ \\
\hline & & & Hasil proyek kerjasama & 5 & 0,1021 & 0 & Rasio $=10 \%$ \\
\hline \multirow[t]{4}{*}{3} & Customer & 0,1408 & Tingkat kepuasan mahasiswa & 19 & 0,3452 & $59,19 \%$ & $>80 \%$ \\
\hline & Satisfaction & & Tingkat kepuasan dosen terhadap BAD & 20 & 0,2326 & $61,5 \%$ & $>80 \%$ \\
\hline & & & $\begin{array}{l}\text { Durasi waktu pembayaran honor rata- } \\
\text { rata }\end{array}$ & 21 & 0,2326 & 27 & $<7$ Hari Kerja \\
\hline & & & Durasi waktu pelayanan per mahasiswa & 18 & 0,1895 & 6 & < 3 Hari Kerja \\
\hline \multirow[t]{4}{*}{4} & Market Size & 0,1134 & $\begin{array}{l}\text { Serapan alumni lapangan kerja sesuai } \\
\text { kompetensi }\end{array}$ & 8 & 0,4720 & $23 \%$ & 40\%/Total Alumni \\
\hline & & & $\begin{array}{l}\text { Serapan alumni pada lapangan kerja } \\
\text { diluar kompetensi }\end{array}$ & 9 & 0,2205 & $44 \%$ & 50\%/Total Alumni \\
\hline & & & $\begin{array}{l}\text { Ketersediaan lapangan pada kerja sesuai } \\
\text { kompetensi }\end{array}$ & 6 & 0,2179 & $38 \%$ & $>50 \%$ \\
\hline & & & $\begin{array}{l}\text { Ketersediaan lapangan kerja diluar } \\
\text { kompetensi }\end{array}$ & 7 & 0,1208 & $57 \%$ & $>70 \%$ \\
\hline \multirow[t]{4}{*}{5} & Productivity & 0,1095 & Rasio jumlah karya ilmiah per dosen & 13 & 0,3833 & $29,0 \%$ & $>60 \%$ \\
\hline & & & $\%$ jumlah mahasiswa tamat tepat waktu & 11 & 0,2501 & $12 \%$ & $>80 \%$ \\
\hline & & & $\begin{array}{l}\text { Rata-rata jumlah penerimaan mahasiswa } \\
\text { baru }\end{array}$ & 10 & 0,1833 & 140,2 & $>120$ Orang \\
\hline & & & Rasio jumlah dosen dengan mahasiswa & 12 & 0,1833 & 0,0392 & $1: 20=(0,05)$ \\
\hline
\end{tabular}

pendidikan dosen), hingga saat ini, dari sebanyak 93 dosen tetap yang ada di Fakultas "X", baru 1 (satu) orang dosen tetap yang telah menyelesaikan pendidikan S3. Artinya, nilai kinerja dasar saat ini baru mencapai nilai 1,07\% yang diperoleh dari perbandingan antara jumlah dosen tetap dengan jumlah dosen yang telah menyelesaikan S3. Adapun target yang ingin dicapai oleh Fakultas " $\mathrm{X}$ " semestinya jumlah dosen yang telah menyelesaikan pendidikan hingga jenjang S3 adalah di atas 30\%. Begitu pula untuk setiap KPI lainnya pada setiap perspektif, penentuan nilai kinerja dasar (baseline kinerja) didasarkan pada data yang ada pada saat ini.

Setelah menetapkan nilai-nilai target untuk setiap KPI, dengan menggunakan metode Objective Matrix (OMAX), dilakukan pengukuran kinerja Fakultas "X" pada tahun 2011 seperti ditunjukkan pada Tabel 4. Perangkingan untuk menentukan pencapaian kinerja setiap KPI dibagi kedalam 4 kategori sesuai grade masing-masing. Kategori pertama dengan nilai grade 10, merupakan tingkat pencapaian kinerja tertinggi sekaligus menjadi target kinerja yang ingin dicapai oleh organisasi. Kategori kedua dengan nilai grade antara 8 hingga
9 merupakan nilai standar ideal pencapaian kinerja yang dapat diraih organisasi. Kategori ketiga merupakan kondisi dimana organisasi belum dapat mencapai target yang dinginkan dengan grade berkisar antara 4 hingga 7. Jika pencapaian kinerja hanya berkisar antara 0-3, maka dapat dikatakan pencapaian kinerja masih jauh dari harapan.

Dari analisis yang telah dilakukan pada KPI yang ada pada perspektif quality, ketiganya belum mampu mencapai target yang diharapkan. Bahkan 2 KPI memiliki nilai indeks kinerja yang masih jauh dari harapan, yakni KPI-33 (jenjang pendidikan dosen) dan KPI-34 (indeks kinerja dosen). Sedangkan KPI-32 (IPK Lulusan) termasuk ke dalam kategori ketiga. Pada perspektif financial, dari 5 KPI yang ada, terdapat 2 KPI telah mampu mencapai target yang diinginkan, yakni KPI-1 (pemasukan dari SPP mahasiswa) dan KPI-2 (pemasukan dari hibah internasional). Hal ini merupakan dampak dari bantuan yang telah diperoleh oleh Fakultas melalui Program Bantuan Islamic Development Bank (IDB). Sedangkan 2 KPI lainnya memiliki indeks pencapaian kinerja justru sangat jauh dari nilai target yang diharapkan, yakni KPI-4 (pemasukan dari Unit Bisnis) dan KPI-5 (proyek kerjasama). 


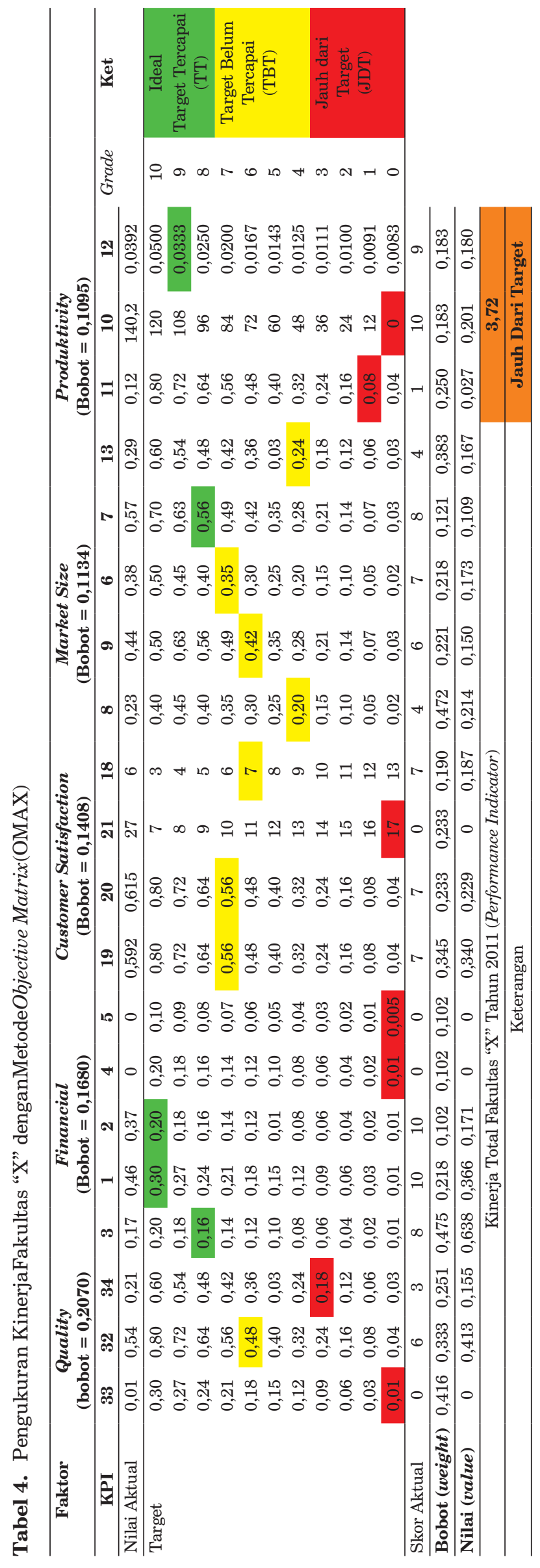

Sedangkan KPI-3 (hibah pemerintah) telah dapat mencapai indeks kinerja yang cukup baik sesuai dengan yang diharapkan.

Pada perspektif customer satisfaction, 3 KPI yakni KPI-18 (durasi waktu pelayanan/mahasiswa), KPI-19 (tingkat kepuasan mahasiswa) dan KPI-20 (tingkat kepuasan dosen terhadap BAD) memiliki nilai indeks 7, sedangkan KPI-21 (waktu rata-rata pembayaran honor) memiliki nilai indeks yang masih jauh dari target yang diharapkan. Pada perspektif market size, diperoleh nilai indeks kinerja pada KPI7 (ketersediaan lapangan kerja di luar kompetensi) telah mencapai target yang dinginkan dengan nilai indeks pada peringkat 8, sedangkan 3 KPI lainnya belum mampu mencapai target yang diharapkan. Sedangkan pada perspektif productivity, diperoleh bahwa terdapat dua KPI yang telah mencapai target yang diharapkan, yakni KPI-10 (rata-rata penerimaan mahasiswa baru) serta KPI-12 (rasio jumlah dosen per mahasiswa). Dua KPI lainnya yakni KPI-11 dan KPI-13 belum dapat mencapai target yang diharapkan.

Dengan memperhatikan bobot prioritas perspektif dan KPI serta nilai kinerja untuk setiap KPI yang diperhatikan, maka diperoleh nilai kinerja Fakultas "X" secara total untuk adalah pada peringkat 3,72 (Tabel 4). Jika dilihat dari standar kinerja yang terbagi ke dalam tiga tingkatan antara lain "target tercapai", "target belum tercapai" dan "jauh dari target", maka dapat diketahui bahwa pencapaian kinerja Fakultas "X" masih "jauh dari target yang diharapkan. Oleh karenanya, hal ini perlu menjadi perhatian dari pihak-pihak berkepentingan pada Fakultas "X", mengingat tahun 2013 yang menjadi landasan pencapaian visi Fakultas hanya tinggal 2 tahun lagi.

\section{SIMPULAN}

Berdasarkan hasil analisis yang telah dilakukan dengan menggunakan metode IPMS, telah ditetapkan sebanyak 32 strategi objektif yang ingin dicapai oleh Fakultas "X". Keseluruhan strategi objektif tersebut terbagi ke dalam 9 (sembilan) perspektif yang merupakan pengembangan dari setiap perspektif yang terdapat pada model SMART system. Melalui 32 strategi objektif tersebut ditentukan pula sebanyak 34 Key Performance Indicator (KPI) yang menjadi ukuran kinerja yang ingin dicapai. Dari pengukuran indeks kinerja yang telah dilakukan terhadap setiap perspektif yang ada, diperoleh nilai indeks kinerja total sebesar 3,72. Jika dibandingkan dengan nilai target ideal pada taraf 10 , atau target pencapaian minimal antara 8-9, maka dapat dikatakan bahwa pencapaian kinerja saat ini sangat jauh dari harapan. Oleh karenanya, hasil ini diharapkan dapat menjadi 
perhatian bagi pihak pengelola, khususnya para pimpinan yang ada di Fakultas "X". Keselarasan antara visi, misi dan strategi objektif perlu diwujudkan. Pelaksanaan manajemen semestinya memiliki batasan yang terukur agar rencana jangka panjang yang telah ditetapkan dapat terwujud sebagaimana mestinya.

\section{DAFTAR PUSTAKA}

Pratiwi, R.P., 2009. Penerapan SMART System Sebagai Metode Pengukuran Kinerja Perusahaan (Studi Kasus: Pada UKM Hentoro Leather).
Saaty, ST.L. 1993. The Analytic HierarchyProsess. McGrawHill. New York.

Suartika, M.I., Suwigno, P. dan Syairuddin, B., 2007. Perancangan dan Implementasi Sistim Pengukuran Kinerja dengan Metode Integrated Performance Measurement System (Studi Kasus: Jurusan Teknik Mesin Mataram). Jurnal Teknik Industri, 9 (2).

Vanany, I. dan Sugianto, A., 2007. Perancangan dan Pengukuran Kinerja Perusahaan Kecil dan Menengah dengan Metode SMART System. Jurnal Manajemen Usahawan Indonesia. PPM UI. 